\title{
STUDI PERILAKU CAMPURAN LATASTON (HRS-WC) DENGAN "LIMBAH KARET BAN LUAR” SEBAGAI BAHAN PENGGANTI SEBAGIANASPAL
}

\author{
Candra Putra Kiswara ${ }^{1} \&$ Andi Saiful $A^{2}$ \\ ${ }^{1 \& 2}$ Jurusan Teknik Sipil Fakultas Teknik Universitas Muhammadiyah Malang \\ Alamat korespondensi : Jalan Raya Tlogomas 246 Malang 65144 \\ e-mail: candra_sum@yahoo.co.id
}

\begin{abstract}
Waste to be one of the problems facing the nation at this time. Community is very disturbed by the presence of various types of waste that is around their neighborhood. Ranging from industrial waste to the waste home. The basic requirements of a road construction is to prepare the surface layer of a flat and strong to ensure high security for a long time and the preservation of every detail in a variety of weather. It required an asphalt mixture that is capable of supporting loads as well as capture the damaging effects of traffic and the weather (climate) and can provide good service. With the addition of waste tire rubber is significantly affect mixture properties such Lataston (HRS-WC) Stability, Marshall Quontient, Flow and Air Voids. This is evidenced by the results of testing using a Marshall. The average value of stability the average of $1220 \mathrm{~kg}$. For Lataston (HRS-WC) mix with additives outer tire rubber to rubber optimum levels (KKO) $11,50 \%$, to produce a mixture of qualities: Marshall Stability value $=1220 \mathrm{~kg}$, Marshall Quotient value $=7,2 \mathrm{kN} / \mathrm{mm}$, Value Air Marshall voids $=10,00 \%$, Value Bitumen film thickness $=5,6 \mathrm{~mm}$.
\end{abstract}

Key Word: Waste Tire Rubber, Marshall Caracteristic

\begin{abstract}
Abstrak
Limbah menjadi salah satu masalah yang dihadapi bangsa saat ini. Masyarakat sangat terganggu oleh kehadiran berbagai jenis limbah yang ada di sekitar lingkungan mereka. Mulai dari limbah industri sampai industri rumah tangga. Persyaratan dasar dari pembangunan jalan adalah untuk mempersiapkan lapisan permukaan datar dan kuat untuk menjamin keamanan yang tinggi untuk waktu yang lama dan pelestarian setiap detail dalam berbagai cuaca. Untuk itu diperlukan suatu campuran aspal yang mampu mendukung beban serta melindungi lalu lintas dari cuaca (iklim) dan dapat memberikan pelayanan yang baik. Dengan penambahan limbah ban karet adalah mempengaruhi sifat campuran tersebut Lataston (HRS-WC) Stabilitas, Marshall Quontient, Aliran Air Void signifikan. Hal ini dibuktikan dengan hasil pengujian menggunakan Marshall. Nilai rata-rata stabilitas rata-rata $1.220 \mathrm{~kg}$. Untuk Lataston (HRSWC) bercampur dengan aditif luar karet ban karet tingkat optimal (KKO) 11,50\%, untuk menghasilkan campuran kualitas: Marshall nilai Stabilitas $=1220 \mathrm{~kg}$, Marshall Quotient nilai $=7,2 \mathrm{kN} / \mathrm{mm}$, nilai Air Marshall void $=10,00 \%$, nilai tebal film aspal $=5,6 \mathrm{~mm}$.
\end{abstract}

Kata Kunci: Limbah Ban Karet, Marshall caracteristic

\section{PENDAHULUAN}

Lapisan tipis aspal beton (HRS/ Lataston) adalah suatu lapisan permukaan (surface course) pada jenis konstruksi perkerasan lentur. Jenis campuran ini merupakan campuran antara aspal dan agregat dengan gradasi senjang, dihampar lalu dipadatkan dalam keadaan panas.

Limbah menjadi salah satu permasalahan serius yang di hadapi bangsa saat ini. Masyarakat sangat merasa terganggu dengan adanya berbagai macam jenis limbah yang ada disekitar lingkungan tempat tinggal mereka. Salah satunya adalah limbah karet ban luar. Limbah karet ban luar itu sendiri adalah karet alam yang telah melewati proses pabrikasi dan sudah melewati penambahan campuran-campuran tertentu kemudian dicetak dalam bentuk ban luar untuk kendaraan bermotor. Dengan menambahkan campuran limbah karet ban luar untuk konstruksi perkerasan jalan pada campuran aspal akan dapat memberikan banyak keuntungan, diantaranya permukaan perkerasan menjadi lebih tahan lama, tahan terhadap retakan akibat lendutan yang berlebihan serta retakan akibat kelelahan bahan. 
Dengan mengacu pada permasalahanpermasalahan di atas maka dibuat rumusan masalah sebagai berikut :

- Bagaimana pengaruh penambahan limbah karet ban luar terhadap karakteristik marshall pada campuran Lataston (HRS-WC)?

- Berapa kadar karet optimum (KKO) yang didapat setelah penambahan beberapa variasi campuran limbah karet ban luar dari hasil pengujian marshall?

Dalam penelitian ini dibuat pembatasan sebagai berikut :

- Tidak membahas analisis kimia yang terjadi pada saat pencampuran dan pengerasan dari limbah karet ban luar.

- Tidak diperhitungkan tentang analisa ekonomi dan efektifitas pekerjaan terhadap penggunaan limbah karet ban luar

\section{Pengertian perkerasan}

Menurut Suprapto (2000), Pengertian perkerasan itu sendiri dalam perkembangannya adalah penggunaan tanah saja tidak cukup kuat dan tahan, tanpa adanya deformasi yang berarti terhadap beban roda berulang. Untuk itu perlu lapis tambahan ini biar di buat dari bahan khusus yang terpilih (yang terbaik), yang selanjutnya lapis keras/perkerasan/ pavement.

\section{Limbah Karet Ban Luar}

Ban merupakan salah satu komponen mobil yang sangat erat kaitannya dengan masalah lingkungan. Dalam proses pembuatan ban konvensional, dibutuhkan bahan-bahan sebagai berikut:

Tabel 1. Komposisi ban

\begin{tabular}{lcc}
\hline \multicolumn{1}{c}{ Deskripsi } & Ban Kendaraan Penumpang & Ban Kendaraan Truk \\
\hline Karet Alam & $14 \%$ & $27 \%$ \\
Karet Sintesis & $27 \%$ & $14 \%$ \\
Carbon Black & $28 \%$ & $28 \%$ \\
Steel & $14-25 \%$ & $14-25 \%$ \\
Fabric, fillers,accelerators, antiozonants, etc & $16-17 \%$ & $16-17 \%$ \\
Berat rata-rata (baru) & $25 \mathrm{lbs}$ & $120 \mathrm{lbs}$ \\
Berat rata-rata (bekas) & $22,5 \mathrm{lbs}$ & $110 \mathrm{lbs}$ \\
\hline
\end{tabular}

Dalam penelitian ini digunakan karet ban luar dari kendaraan truk. Kelebihan yang dimiliki karet alam dibandingkan karet sintetis adalah memiliki daya elastisitas dan daya lenting sempurna, memiliki plastisasi yang baik sehingga pengolahannya mudah, mempunyai daya aus yang tinggi, tidak mudah panas (low heat bid up), dan memiliki daya tahan tinggi terhadap keretakan. Sedangkan Karet sintetis memiliki kelebihan untuk beberapa keadaan diantaranya tahan terhadap berbagai zat kimia, harga cenderung bisa dipertahankan supaya tetap stabil.

\section{Lapisan Tipis Aspal Beton (Lataston)}

Pusat Litbang Prasarana Transportasi (2005: 6-19) menjelaskan bahwa terdapat dua campuran Lataston sebagai pelapis atas yaitu:

- Lataston Lapis Aus (HRS-Wearing Course), Ukuran maksimum butiran agregat pada campuran Lataston adalah $19 \mathrm{~mm}$ (3/4"). Karakteristik perkerasan yang diutamakan adalah keawetan, fleksibilitas (kelenturan) dan daya tahan terhadap kerusakan.

- Lataston Lapis Pondasi (HRS-Base), pada lapis pondasi terdapat proporsi fraksi agregat kasar lebih besar dari pada Lataston Lapis Aus (HRS-Wearing Course).

Direktorat Jenderal Bina Marga (1996 : 27) menerangkan bahwa HRS/Lataston merupakan suatu lapisan permukaan konstruksi jalan yang sebaiknya memikul lalu lintas ringan sampai sedang $(<1.000 .000$ ES A). Karakteristik yang paling penting adalah keawetan, fleksibilitas dan ketahanan kelelehan yang tinggi.

Sifat-sifat Campuran Aspal dapat dilihat pada tabel 2 .

\section{METODE PENELITIAN}

\section{Tempat Penelitian}

Pelaksanaan penelitian dilaksanakan di Laboratorium Jalan Raya Fakultas Teknik Sipil Universitas Muhammadiyah Malang. 


\section{Rancangan Penelitian}

Benda Uji tahap I merupakan campuran Lataston (HRS-WC) murni dan dibuat sebanyak 15 benda uji. Setelah didapatkan kadar aspal optimum, kadar aspal optimum digunakan untuk pembuatan benda uji II dengan ditambah limbah karet ban luar dengan variasi $5 \%, 10 \%, 15 \%, 20 \%, 25 \%$ dari kadar aspal optimum, dengan mengurangi kadar aspal optimum. Benda uji tahap II dibuat sebanyak 5 kelompok dan setiap kelompok ada 3 benda uji sehingga ada 15 benda uji.

Tabel 2. Ketentuan Sifat - Sifat Campuran Aspal

\begin{tabular}{|c|c|c|c|}
\hline \multirow{2}{*}{\multicolumn{2}{|c|}{ Sifat - Sifat Campuran }} & \multicolumn{2}{|c|}{ Lataston } \\
\hline & & $\mathrm{WC}$ & Base \\
\hline Kadar aspal efektif (\%) & Min & & \\
\hline Jumlah tumbukan per bidang & & & \\
\hline Stabilitas Marshall (kg) & Min & & \\
\hline Marshall Quotient $(\mathrm{kg} / \mathrm{mm})$ & Min & & \\
\hline & Min & & \\
\hline Kongga dalam Campuran, vivi(\%) & $\operatorname{Max}$ & & \\
\hline Rongga dalam Agregat, VMA (\%) & Min & 18 & 17 \\
\hline Kelelehan (mm) & Min & & \\
\hline Rongga Terisi Aspal, VFA & Min & & \\
\hline
\end{tabular}

Tahapan Penelitian

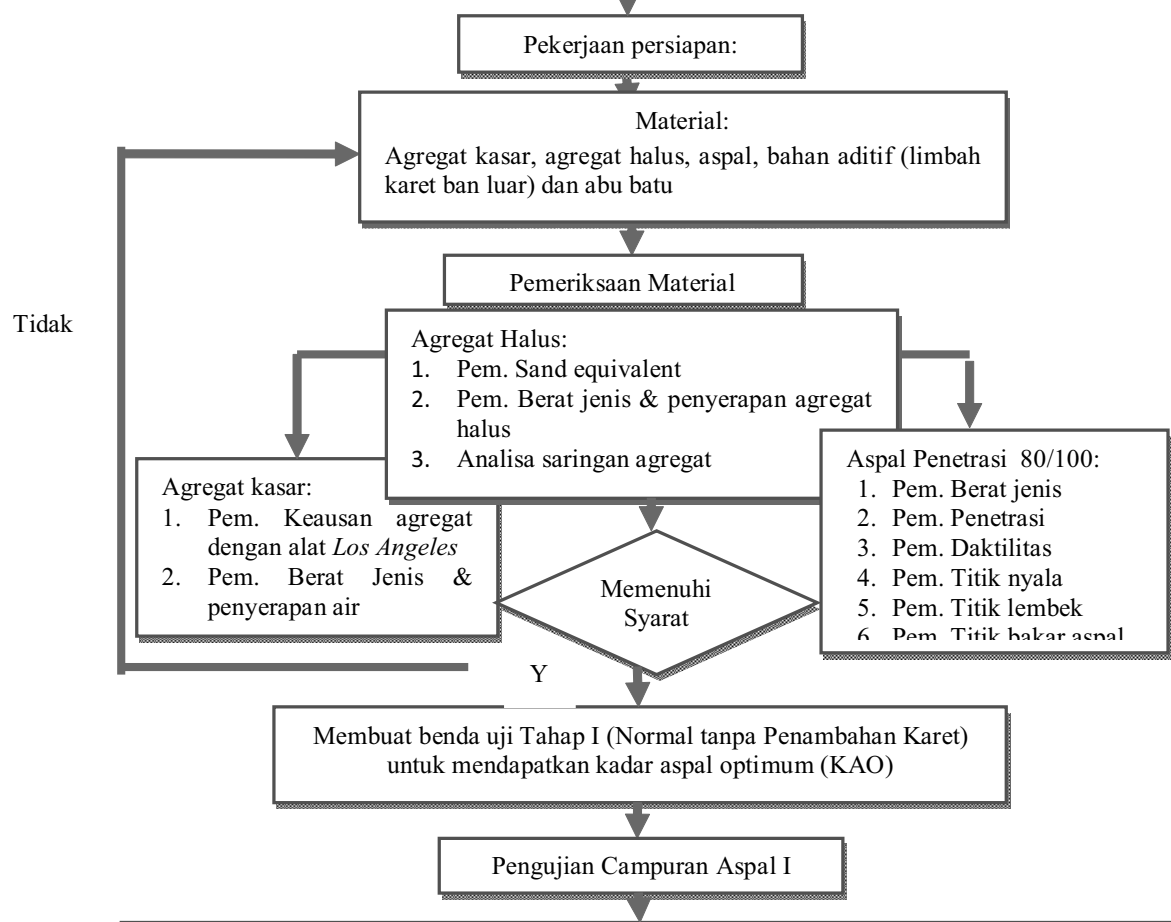

Membuat benda uji Tahap II (dengan penambahan limbah karet ban luar) untuk mendapatkan kadar karet optimum (KKO), dengan variasi 5\%, 10\%, 15\%, 20\%, 25\%

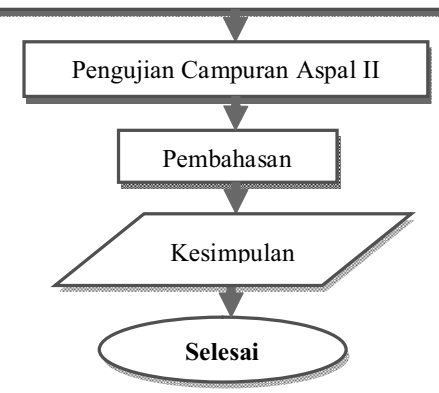

Gambar 1. Diagram Alur Penelitian 


\section{HASIL DAN PEMBAHASAN}

Hasil Pemeriksaan Mutu Bahan

Pemeriksaan Agregat Dengan Mesin Los Angeles

Hasil pemeriksaan dengan mesin Los Angeles menghasilkan keausan agregat sebesar 28,5 \% (keausan agregat maximum $40 \%$ ).

Pemeriksaan Berat Jenis dan Penyerapan Agregat Kasar

Dari hasil pemeriksaan berat jenis dan penyerapan agregat kasar menghasilkan:

- Berat jenis (atas dasar kering oven) rata-rata $=2,65 \%$

- Berat jenis (atas dasar kering permukaan) ratarata $=2,70 \%$

- $\quad$ Berat jenis semu rata-rata $(\min 2,5)=2,79 \%$

- $\quad$ Penyerapan air rata-rata $(\operatorname{mak} 3 \%)=1,93 \%$

Pemeriksaan Berat Jenis dan Penyerapan Agregat Halus(Pasir Alam)

Dari hasil pemeriksaan berat jenis dan penyerapan agregat halus menghasilkan:

- Berat jenis (atas dasar kering oven) rata-rata $=2.50 \%$

- Berat jenis (atas dasar kering permukaan) ratarata $=2.52 \%$

- Berat jenis semu rata-rata $(\min 2.5)=2.61 \%$

- Penyerapan air rata-rata $(\operatorname{mak} 3 \%)=1.24 \%$

Pemeriksaan Berat Jenis dan Penyerapan Agregat Halus(Abu Batu)

Dari hasil pemeriksaan berat jenis dan penyerapan agregat halus menghasilkan:

- Berat jenis (atas dasar kering oven) rata-rata $=2,50 \%$

- Berat jenis (atas dasar kering permukaan) ratarata $=2,53 \%$

- $\quad$ Berat jenis semu rata-rata $(\min 2,5)=2.62 \%$

- $\quad$ Penyerapan air rata-rata $(\operatorname{mak} 3 \%)=2.25 \%$

Pemeriksaan Sand Equivalent Agregat Halus

Dari hasil pemeriksaan Sand Equivalent Pasir Alam pada tabel 4.4 menghasilkan nilai rata-rata http://ejournal.umm.ac.id/index.php/jmts/article/view/2037

Sand Equivalent $90 \%$ (batas minimum 50\%) dan untuk abu batu menghasilkan nilai rata-rata Sand Equivalent $83.05 \%$ (batas minimum 50\%).

\section{Pemeriksaan Analisa Saringan Agregat Kasar Dan Agregat Halus}

Dari hasil pemeriksaan saringan pada agregat kasar dan halus ini berat tertahan. Agregat kasar masuk dalam campuran normal, agregat halus (pasir alam dan abu batu) masuk dalam spesifikasi Lataston. Berikut Hasil Pemeriksaan AspalPemeriksaan Penetrasi Aspal.

Tabel 3. Hasil Pemeriksaan Penetrasi Aspal

\begin{tabular}{cc}
\hline Pengamatan & Hasil \\
\hline I & $97 \mathrm{~mm}$ \\
II & $82 \mathrm{~mm}$ \\
III & $86 \mathrm{~mm}$ \\
Rata - Rata & $=88,33 \mathrm{~mm}$ \\
\hline
\end{tabular}

Sumber: Hasil Penelitian

\section{Pemeriksaan Titik Lembek}

Titik lembek dilakukan 3 kali percobaan dan didapat hasil sebagai berikut:

- $\quad 47^{\circ} \mathrm{C}$

- $46,25 \mathrm{C}$

- 51

\section{Pemeriksaan Titik Nyala dan Titik Bakar} Dengan Cleveland Open Cup

- Titik nyala aspal $=289^{\circ} \mathrm{C}$

- Titik bakar aspal $=300^{\circ} \mathrm{C}$

\section{Pemeriksaan Daktilitas Bahan-Bahan Bitumen}

Daktilitas dilakukan 3x percobaan dan didapat hasil sebagai berikut:

- $110 \mathrm{~cm}$

- $131 \mathrm{~cm}$

- $117 \mathrm{~cm}$

Nilai rata-rata daktilitas aspal adalah 113,50 $\mathrm{cm}$ 


\section{Pemeriksaan Berat Jenis Aspal}

Tabel 4. Hasil Pemeriksaan Berat Jenis Aspal

\begin{tabular}{cc}
\hline Nilai & gr \\
\hline $\mathrm{A}$ & 37.7 \\
$\mathrm{~B}$ & 130.6 \\
$\mathrm{C}$ & 84.1 \\
$\mathrm{D}$ & 131.8 \\
\hline$\frac{(C-A)}{(B-A)-(D-C)} \frac{(84.1-37.7)}{(130.6-37.7)-(131.8-84.1)}$
\end{tabular}

$$
=1,027 \mathrm{gr} / \mathrm{cm}^{3}
$$

\section{Perencanaan Komposisi Campuran}

\section{Pemilihan Dan Penentuan Sifat-Sifat Agregat Campuran Lataston (HRS - Wearing Course)}

Berdasarkan fraksi-fraksi agregat campuran Lataston (HRS-WC) dan rancangan campuran nominal, dengan menggunakan metode matrik dan berdasarkan perbandingan antara pasir alam dengan abu batu (49\%:51\%) maka proporsi rancangan campuran dapat dilihat pada tabel 5 .

Tabel 5. Proporsi Campuran Nominal Disesuaikan

\begin{tabular}{ccccccc}
\hline MATERIAL & $\begin{array}{c}\text { Campuran } \\
\text { Nominal } \\
\text { Perhitungan }\end{array}$ & \multicolumn{5}{c}{ Campuran Nominal Disesuaikan } \\
& $30,09 \%$ & $30,09 \%$ & $30,09 \%$ & $30,09 \%$ & $30,09 \%$ & $30,09 \%$ \\
\hline Batu Pecah & $29,18 \%$ & $30,18 \%$ & $29,68 \%$ & $29,18 \%$ & $28,68 \%$ & $28,18 \%$ \\
Abu Batu & $28,04 \%$ & $29,04 \%$ & $28,54 \%$ & $28,04 \%$ & $27,54 \%$ & $27,04 \%$ \\
Pasir Alam & $5,09 \%$ & $5,09 \%$ & $5,09 \%$ & $5,09 \%$ & $5,09 \%$ & $5,09 \%$ \\
Bahan Pengisi & $7,60 \%$ & $5,60 \%$ & $6,60 \%$ & $7,60 \%$ & $8,60 \%$ & $9,6 \%$ \\
Aspal ( A ) & $100,00 \%$ & $100,00 \%$ & $100,00 \%$ & $100,00 \%$ & $100,00 \%$ & $100,00 \%$ \\
TOTAL & & & & & & \\
\hline
\end{tabular}

Berdasarkan gambar 2, hampir semua (variasi $5,6 \%, 6,6 \%, 7,6 \%, 8,6 \%$ ) benda uji masuk dalam persyaratan nilai Marshall Stability yaitu min 800

kg. Sehingga campuran Lataston (HRS-WC) bisa diaplikasikan di lapangan berdasarkan persyaratan Marshall Stability.

Tabel 6. Rangkuman Sifat- Sifat Campuran Aspal Dengan Metode Alat Marshall

\begin{tabular}{|c|c|c|c|c|c|c|c|c|}
\hline \multirow[b]{2}{*}{$\begin{array}{l}\text { No. } \\
\text { Benda } \\
\text { Uji }\end{array}$} & \multirow[b]{2}{*}{$\begin{array}{l}\text { Kadar } \\
\text { Aspal }\end{array}$} & \multirow[b]{2}{*}{$\begin{array}{c}\text { Isi Benda } \\
\text { Uji }\end{array}$} & \multirow[b]{2}{*}{$\begin{array}{l}\text { Rongga } \\
\text { Udara }\end{array}$} & \multicolumn{2}{|c|}{ Stabilitas-(K g) } & \multirow[b]{2}{*}{$\begin{array}{c}\text { Hasil bagi } \\
\text { Marshal } \\
(\mathrm{kn} / \mathrm{mm})\end{array}$} & \multirow{2}{*}{$\begin{array}{c}\text { Luas } \\
\text { Permuk. } \\
\text { Agregat } \\
\left(\mathrm{m}^{2} / \mathrm{Kg}\right) \\
\end{array}$} & \multirow{2}{*}{$\begin{array}{c}\text { Tabel } \\
\text { Lapisan } \\
\text { Aspal Film } \\
\text { (un) }\end{array}$} \\
\hline & & & & Di Baca & Disesuaikan & & & \\
\hline $1 . \mathrm{A}$ & 5,60 & 495,00 & 3,41 & 79 & 1359,7 & & & \\
\hline 1.B & 5,60 & 540,00 & 10,76 & 73 & 1260,5 & & & \\
\hline $1 \mathrm{C}$ & 5,60 & 513,00 & 5,17 & 98 & 1584,2 & & & \\
\hline Rata-rata & & & 6,45 & & 1401,5 & 7,49 & 8,69 & 6,04 \\
\hline 2.A & 6,60 & 496,00 & $-1,23$ & 115 & 1910,7 & & & \\
\hline 2.B & 6,60 & 492,00 & 0,61 & 74 & 1338,5 & & & \\
\hline $2 \mathrm{C}$ & 6,60 & 500,00 & 3,47 & 144 & 2254,3 & & & \\
\hline Rata-rata & & & 0,95 & & 1834,5 & 7,01 & 8,69 & 7,31 \\
\hline 3.A & 7,60 & 498,00 & $-1,17$ & 82 & 1354,9 & & & \\
\hline 3.B & 7,60 & 505,00 & $-1,55$ & 95 & 1542,1 & & & \\
\hline $3 \mathrm{C}$ & 7,60 & 486,00 & $-1,56$ & 104 & 1821,9 & & & \\
\hline Rata-rata & & & $-1,42$ & & 1573,0 & 6,06 & 8,96 & 8,61 \\
\hline 4.A & 8,60 & 500,00 & $-1,69$ & 69 & 1194,0 & & & \\
\hline 4.B & 8,60 & 503,00 & $-1,86$ & 56 & 1007,5 & & & \\
\hline $4 \mathrm{C}$ & 8,60 & 505,00 & $-1,72$ & 92 & 1559,5 & & & \\
\hline Rata-rata & & & $-1,76$ & & 1253,7 & 4,12 & 8,68 & 9,94 \\
\hline $5 . \mathrm{A}$ & 9,60 & 504,00 & $-2,06$ & 43 & 817,7 & & & \\
\hline 5.B & 9,60 & 492,00 & $-1,87$ & 41 & 789,1 & & & \\
\hline $5 \mathrm{C}$ & 9,60 & 497,00 & $-2,35$ & 38 & 744,6 & & & \\
\hline Rata-rata & & & $-2,09$ & & 783,8 & 2,92 & 8,68 & 11,30 \\
\hline
\end{tabular}




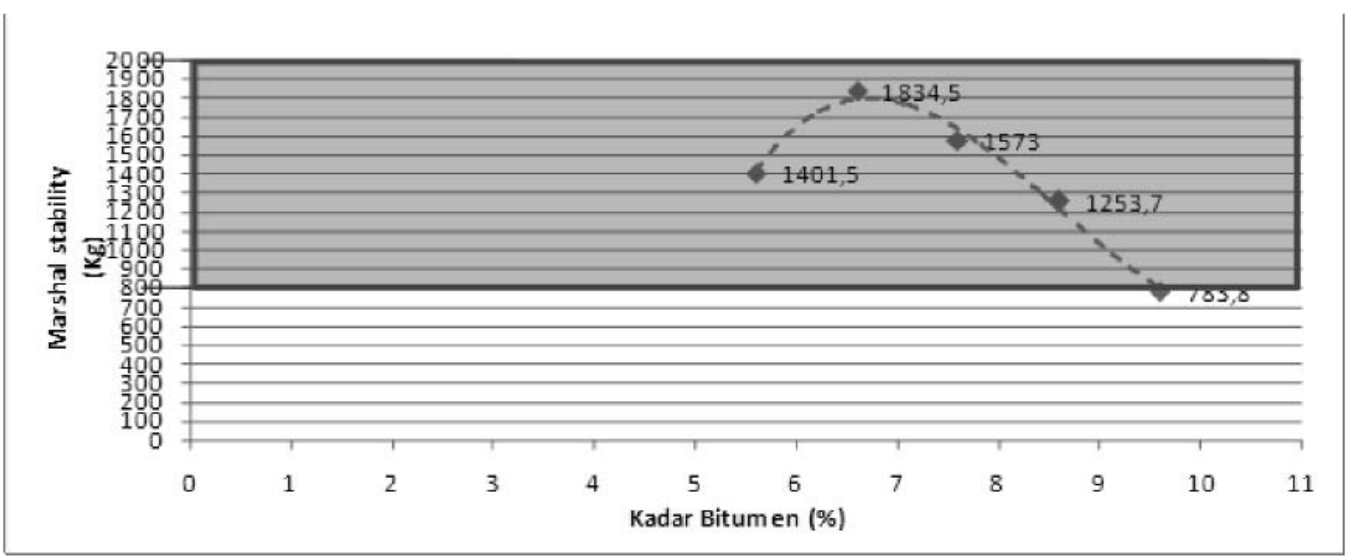

Gambar 2. Grafik Hubungan Aspal dengan Stabilitas Marshall Campuran Lataston HRS-WC (Standar)

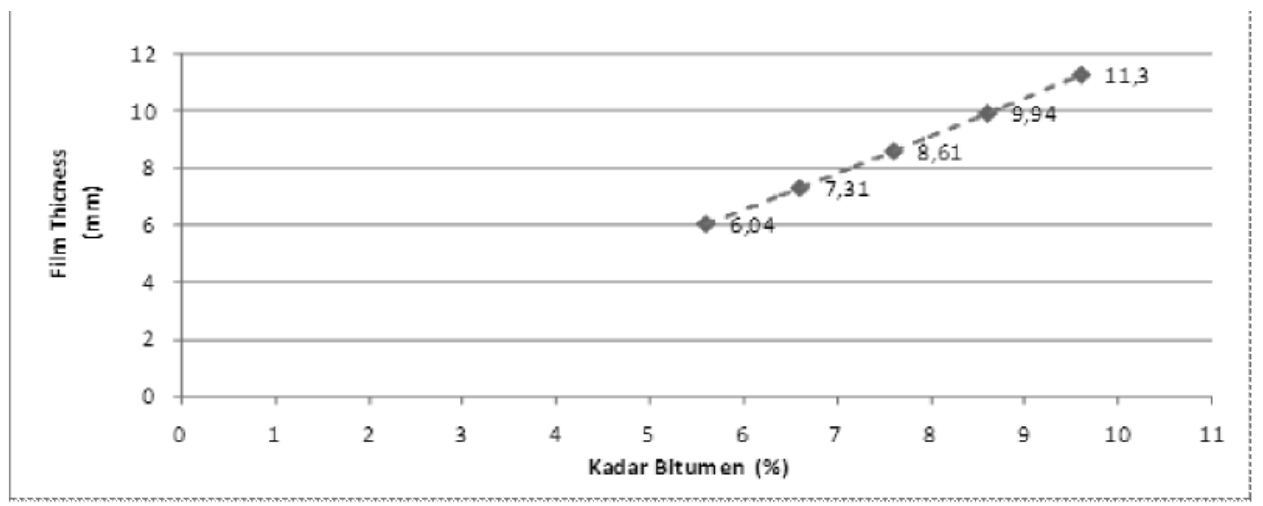

Gambar 3. Grafik Hubungan Aspal dengan Film Thickness Campuran Lataston HRS-WC (Standar)

Karena tidak ada persyaratan minimum atau maksimum nilai Film Thickness, sehingga campuran

Lataston (HRS-WC) bisa di aplikasikan di lapangan.

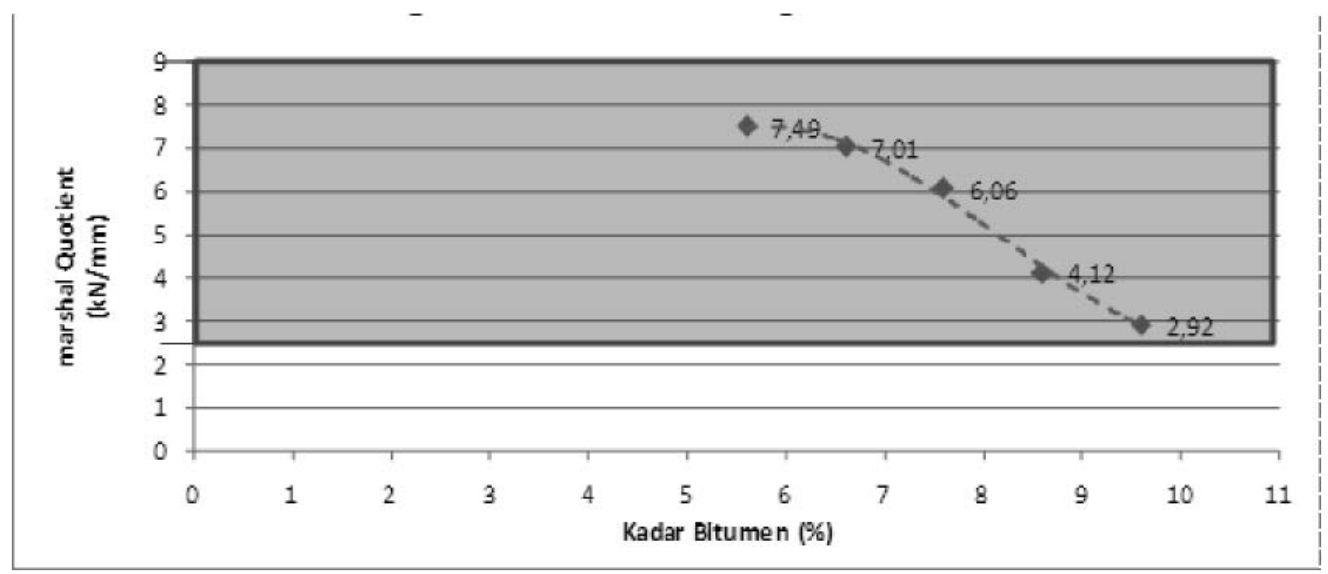

Gambar 4. Grafik Hubungan Aspal dengan Marshall Quoetient Campuran Lataston HRS-

Menurut gambar 4, semua benda uji masuk dalam syarat minimum nilai Marshall Quotient yaitu $\min 2,5 \mathrm{kN} / \mathrm{mm}$. Sehingga campuran Lataston
(HRS-WC) bisa diaplikasikan di lapangan berdasarkan persyaratan Marshall Quotient. 


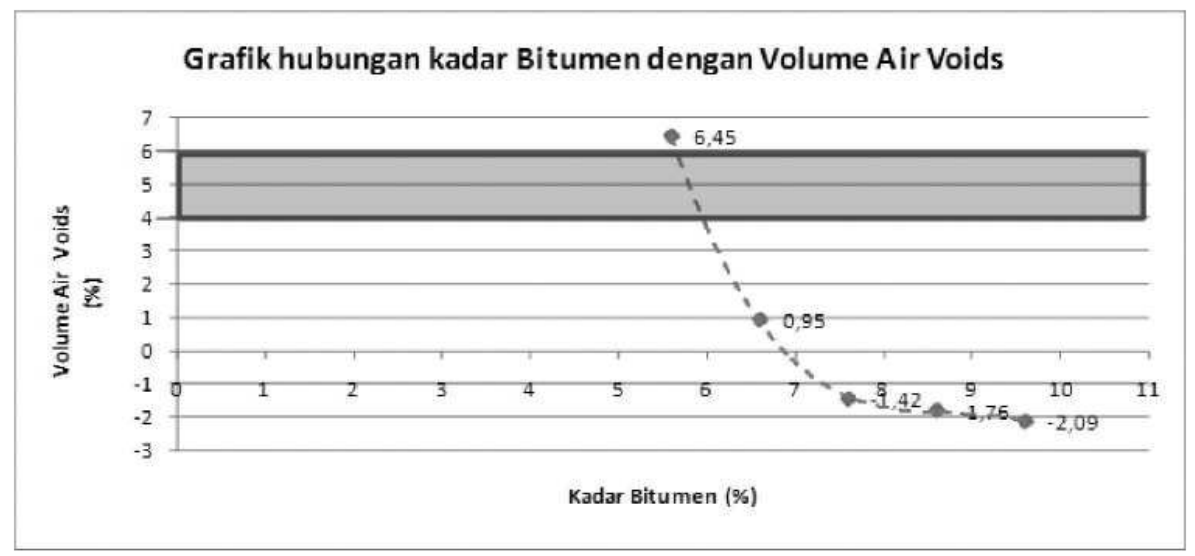

Gambar 5. Grafik Hubungan Aspal dengan Air Void Campuran Lataston HRS-WC (Standar)

Berdasarkan gambar 5, semua benda uji tidak masuk dalam persyaratan Volume Air Void yaitu 4\% - 6\%. Akan tetapi campuran Lataston (HRS-WC) dengan variasi $5,6 \%$ bitumen diatas syarat maksimum Air Void dan yang lainnya dibawah syarat minimum. Sehingga apabila dihubungkan garis nilai kadar aspal 5,9\% dapat diaplikasikan di lapangan dengan syarat Volume Air Void terpeuhi.

Dari gambar 2, 3, 4 dan 5, campuran aspal Lataston (HRS-WC) dengan kadar aspal optimum $5,9 \%$ dengan karakteristik Stabilitas Marshall $=1550$
$\mathrm{Kg}$, Marshall Quotient $=7,49 \mathrm{Kn} / \mathrm{mm}$, Air Voids $=$ $4,60 \%$ dan Film Thikness $=6,4 \mathrm{Mm}$

\section{Pemeriksaan Sifat Campuran Menggunakan Aspal Optimum}

Kadar aspal optimum yang diperoleh adalah $5,9 \%$. Supaya campuran total tetap $100 \%$, maka proporsi abu batu dan pasir perlu disesuaikan dengan filler $5,09 \%$.

Tabel 7. Menentukan Proporsi Campuran Lataston (HRS-WC)

\begin{tabular}{ccccccc}
\hline \multirow{3}{*}{ MATERIAL } & $\begin{array}{c}\text { Campuran } \\
\text { Nominal } \\
\text { Perhitungan }\end{array}$ & $5 \%$ & $10 \%$ & $15 \%$ & $20 \%$ & $25 \%$ \\
\hline Batu Pecah & $30,09 \%$ & $30,09 \%$ & $30,09 \%$ & $30,09 \%$ & $30,09 \%$ & $30,09 \%$ \\
Abu Batu & $30,05 \%$ & $30,05 \%$ & $30,05 \%$ & $30,05 \%$ & $30,05 \%$ & $30,05 \%$ \\
Pasir Alam & $28,87 \%$ & $28,87 \%$ & $28,87 \%$ & $28,87 \%$ & $28,87 \%$ & $28,87 \%$ \\
Bahan Pengisi & $5,09 \%$ & $5,09 \%$ & $5,09 \%$ & $5,09 \%$ & $5,09 \%$ & $5,09 \%$ \\
Aspal ( A ) & $5,90 \%$ & $5,61 \%$ & $5,31 \%$ & $5,02 \%$ & $4,72 \%$ & $4,43 \%$ \\
Karet & $0 \%$ & $0,30 \%$ & $0,59 \%$ & $0,89 \%$ & $1,18 \%$ & $1,48 \%$ \\
TOTAL & $100,00 \%$ & $100,00 \%$ & $100,00 \%$ & $100,00 \%$ & $100,00 \%$ & $100,00 \%$ \\
\hline
\end{tabular}

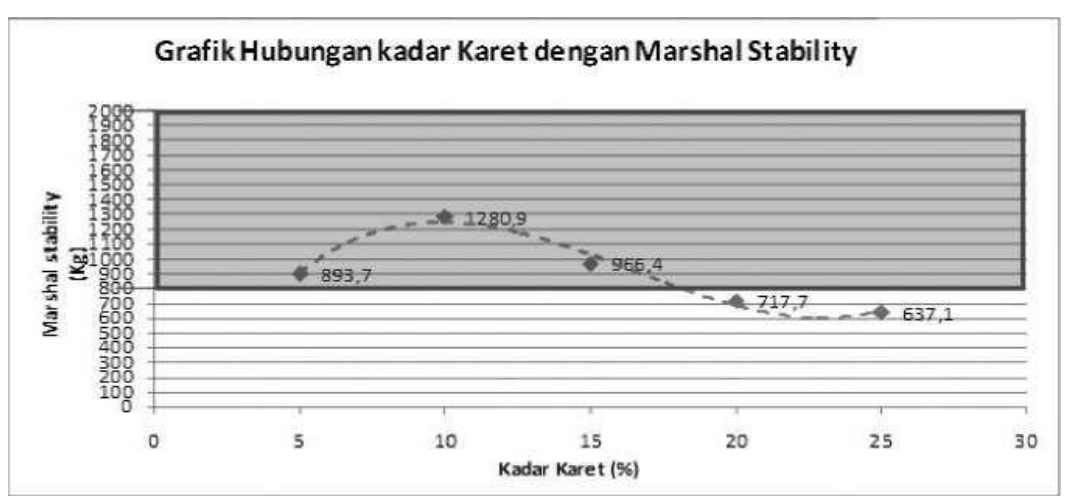

Gambar 6. Grafik Hubungan Karet dengan Stabilitas Marshall Campuran Lataston (HRS-WC) dengan penambahan "Limbah Karet Ban Luar" 
Tabel 8. Rangkuman Sifat- Sifat Campuran Aspal Karet Dengan Metode Alat Marshall

\begin{tabular}{|c|c|c|c|c|c|c|c|c|}
\hline \multirow[b]{2}{*}{$\begin{array}{l}\text { No. } \\
\text { Benda } \\
\text { Uji }\end{array}$} & \multirow[b]{2}{*}{$\begin{array}{l}\text { Kadar } \\
\text { Aspal }\end{array}$} & \multirow[b]{2}{*}{$\begin{array}{c}\text { Isi Benda } \\
\text { Uji }\end{array}$} & \multirow[b]{2}{*}{$\begin{array}{c}\text { Rongga } \\
\text { Udara }\end{array}$} & \multicolumn{2}{|c|}{ Stabilitas-(K g) } & \multirow[b]{2}{*}{$\begin{array}{l}\text { Hasil bagi } \\
\text { Marshal } \\
(\mathrm{kn} / \mathrm{mm})\end{array}$} & \multirow{2}{*}{$\begin{array}{c}\text { Luas } \\
\text { Permuk. } \\
\text { Agregat } \\
\left(\mathrm{m}^{2} / \mathrm{Kg}\right)\end{array}$} & \multirow{2}{*}{$\begin{array}{c}\text { Tabel } \\
\text { Lapisan } \\
\text { Aspal Film } \\
\text { (un) }\end{array}$} \\
\hline & & & & Di Baca & Disesuaikan & & & \\
\hline 1.A & 5,61 & 431,00 & 8,47 & 37 & 652,1 & 5,81 & & \\
\hline 1.B & 5,61 & 540,00 & 9,92 & 52 & 850,0 & 4,82 & & \\
\hline $1 \mathrm{C}$ & 5,61 & 534,00 & 6,96 & 74 & 1178.8 & 10,60 & & \\
\hline Rata-rata & & & 8,45 & & 893,7 & 6,71 & 8,69 & 6,05 \\
\hline $2 . \mathrm{A}$ & 5,31 & 544,00 & 9,85 & 66 & 978,7 & 4,85 & & \\
\hline 2.B & 5,31 & 544,00 & 9,05 & 116 & 1648,5 & 9,18 & & \\
\hline $2 \mathrm{C}$ & 5,31 & 545,00 & 8,84 & 86 & 1215,4 & 8,22 & & \\
\hline Rata-rata & & & 9,16 & & 1280,9 & 7,26 & 8,69 & 5,68 \\
\hline 3.A & 5,02 & 558,00 & 11,56 & 68 & 975,6 & 7,34 & & \\
\hline 3. B & 5,02 & 568,00 & 13,62 & 58 & 885,9 & 4,28 & & \\
\hline $3 \mathrm{C}$ & 5,02 & 562,00 & 12,19 & 75 & 1069,7 & 8,07 & & \\
\hline Rata-rata & & & 12,46 & & 966,4 & 6,23 & 8,96 & 5,31 \\
\hline $4 . \mathrm{A}$ & 4,72 & 581,00 & 15,56 & 42 & 625,8 & 2,29 & & \\
\hline 4. $\mathrm{B}$ & 4,72 & 569,00 & 14,28 & 56 & 804,0 & 3,75 & & \\
\hline $4 \mathrm{C}$ & 4,72 & 571,00 & 13,79 & 49 & 723,3 & 6,45 & & \\
\hline Rata-rata & & & 14,54 & & 717,7 & 4,02 & 8,69 & 4,95 \\
\hline $5 . \mathrm{A}$ & 4,43 & 584,00 & 16,07 & 47 & 682,3 & 6,37 & & \\
\hline 5.B & 4,43 & 552,00 & 13,20 & 37 & 603,1 & 4,38 & & \\
\hline $5 \mathrm{C}$ & 4,43 & 576,00 & 15,40 & 42 & 625,8 & 3,61 & & \\
\hline Rata-rata & & & 14,89 & & 637,1 & 4,57 & 8,69 & 4,58 \\
\hline
\end{tabular}

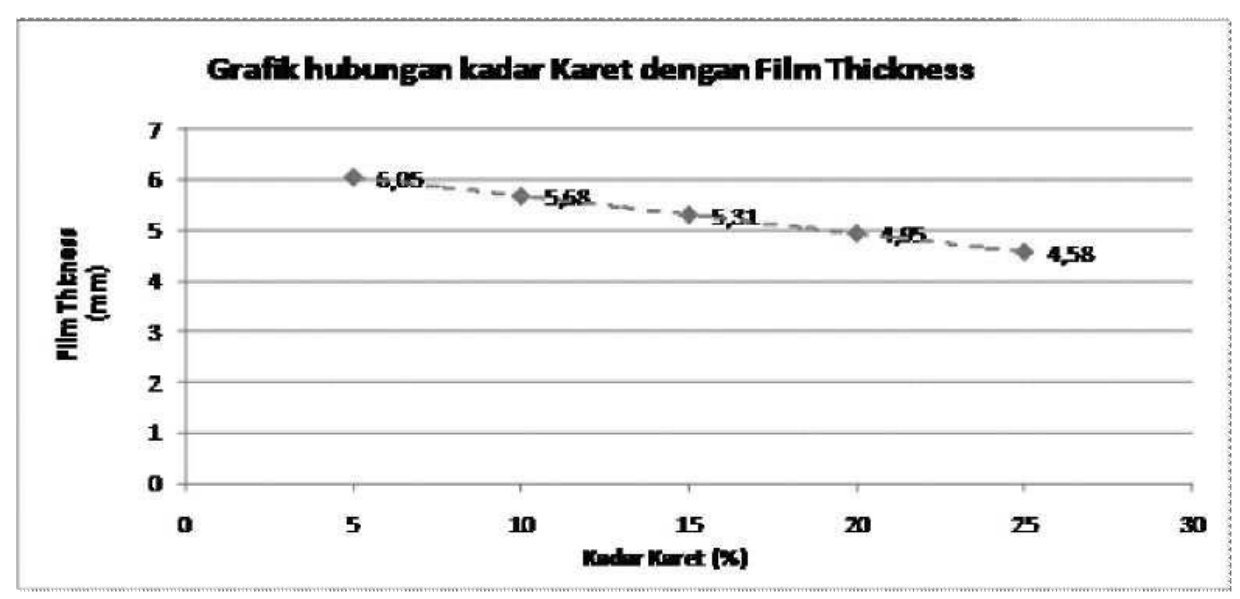

Gambar 7. Grafik Hubungan Karet dengan Film Thickness Campuran Lataston (HRS-WC) dengan penambahan "Limbah Karet Ban Luar"

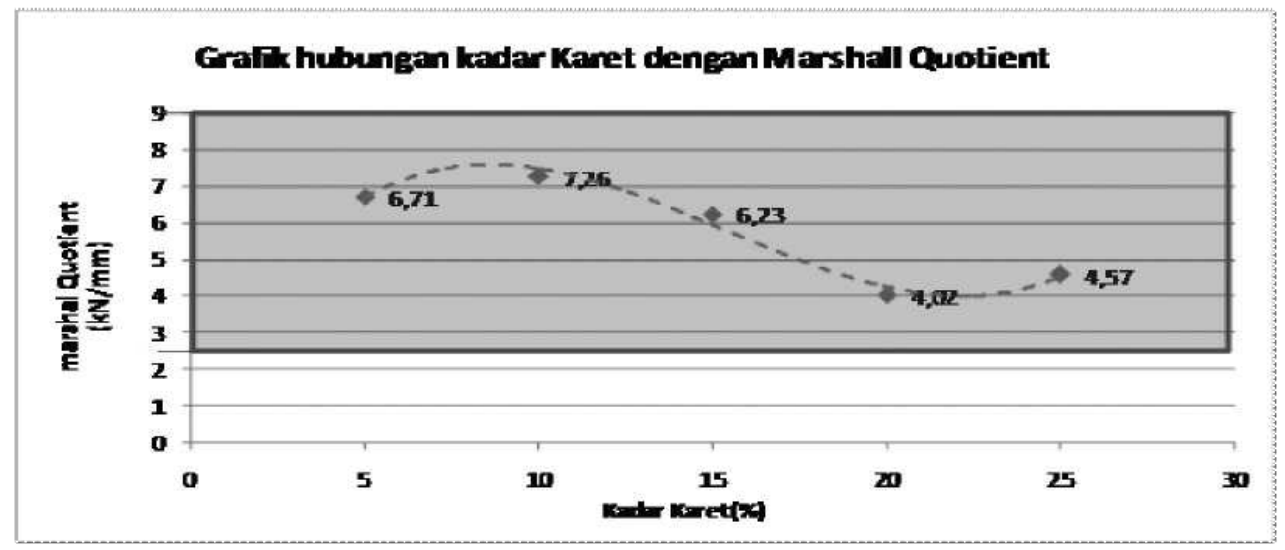

Gambar 8. Grafik Hubungan Karet dengan Marshall Quotient Campuran Lataston (HRS-WC) dengan penambahan "Limbah Karet Ban Luar" 


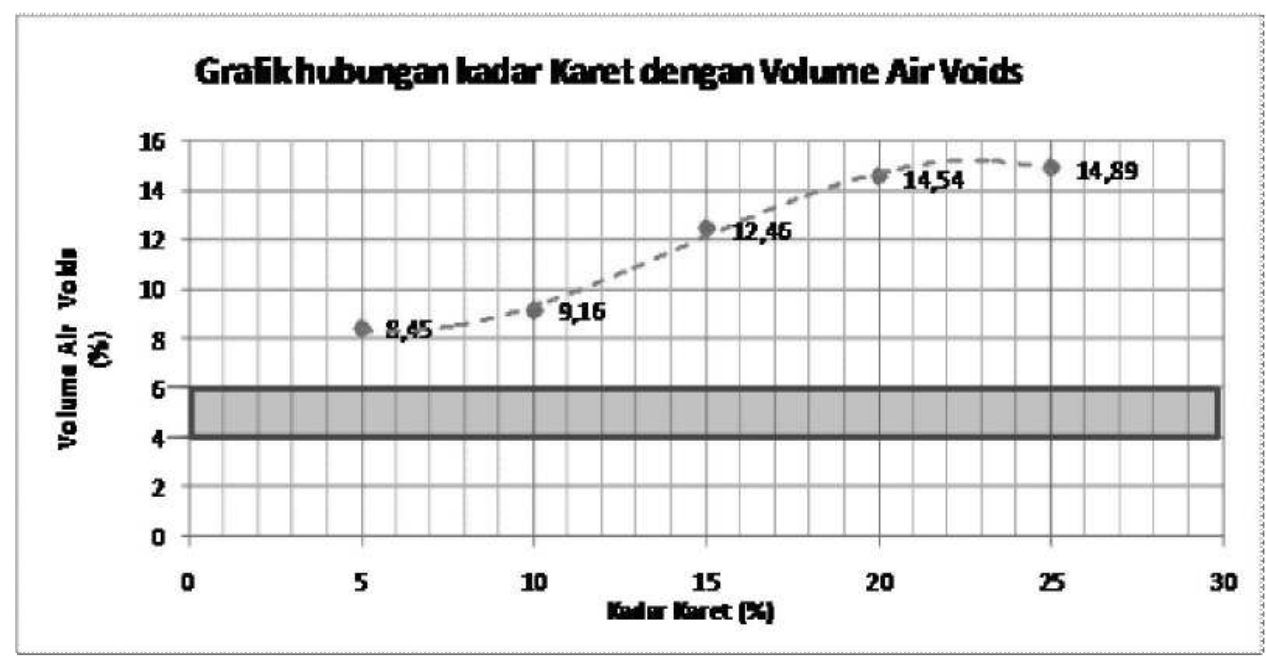

Gambar 9. Grafik Hubungan Karet dengan Volume Air Void Campuran Lataston (HRS-WC) dengan penambahan "Limbah Karet Ban Luar"

Berdasarkan gambat 7 , karena tidak ada persyaratan minimum atau maksimum nilai Film Thickness, sehingga campuran Lataston (HRS-WC) bisa diaplikasikan di lapangan.

Berdasarkan gambar 8 diatas, semua benda uji masuk dalam syarat minimum nilai Marshall Quotient yaitu $\min 2,5 \mathrm{kN} / \mathrm{mm}$. Sehingga campuran Lataston (HRS-WC) bisa diaplikasikan di lapangan berdasarkan persyaratan Marshall Quotient.

\section{Stabilitas Marshall}

Berdasarkan hasil pemeriksaan nilai Stabilitas diperoleh bahwa limbah karet ban luar sebagai pengganti aspal pada campuran Aspal Treated Base (ATB) menghasilkan stabilitas $1220 \mathrm{Kg}$, mengalami penurunan dari hasil campuran tanpa menggunakan limbah karet ban luar $1550 \mathrm{Kg}$.

\section{Marshall Quotient}

Berdasarkan hasil pemeriksaan diperoleh bahwa dengan penambahan limbah karet ban luar sebagai pengganti aspal pada campuran Lataston HRS-WC menghasilkan Marshall Quotient 7,2 kN/ $\mathrm{mm}$ mengalami penurunan dari hasil yang tanpa menggunakan limbah karet ban luar 7,49 kN/mm. Sehingga campuran Lataston HRS-WC dengan penambahan karet ban luar lebih lentur atau plastis.

\section{Air Void}

Berdasarkan hasil pemeriksaan setelah adanya penambahan limbah karet ban luar pada campuran Lataston HRS-WC mengalami peningkatan persentase rongga udara. Pada campuran normal didapatkan persentase rongga udara sebesar $4,6 \%$, dan setelah menggunakan bahan tambahan limbah karet ban luar didapatkan persentase rongga udara sebesar $10 \%$. Hal ini dikarenakan karet ban luar memiliki berat jenis 50\% lebih kecil dibandingkan berat jenis campuran sehingga didapat campuran yang lebih ringan dan lentur apabila dibandingkan tanpa penambahan karet ban luar.

\section{Film Thickness}

Berdasarkan hasil pemeriksaan diperoleh bahwa dengan penambahan limbah karet ban luar sebagai pengganti aspal pada campuran Lataston HRS-WC menghasilkan nilai film thickness 5,6 kN/ $\mathrm{mm}$ mengalami penurunan dari hasil yang tanpa menggunakan limbah karet ban luar $6,4 \mathrm{kN} / \mathrm{mm}$.

\section{Kadar Karet Optimum}

Dengan menggunakan grafik hubungan antara penambahan karet ban luar dengan parameter Marshall dapat diketahui Kadar Karet Optimum. Kadar karet terbaik berdasarkan grafik adalah 11,50 $\%$. 


\section{KESIMPULAN DAN SARAN}

Kesimpulan

- $\quad$ Berdasarkan pengujian dengan alat marshall diketahui bahwa penggunaan limbah karet ban luar sebagai pengganti aspal memberikan pengaruh yang signifikan terhadap karakteristik Marshall terutama pada Air Void yang semula 4,60\% sebelum ditambah karet ban luar menjadi $10,00 \%$ setelah ditambah karet ban luar di campuran Lataston HRS-WC

- Untuk campuran Lataston HRS-WC dengan bahan aditif karet ban luar di dapat kadar karet optimum (KKO) 11,50\% dari kadar aspal optimum 5,90\%, dengan menghasilkan kualitas campuran aspal sebagai berikut:

- Nilai Marshall Stability $=1220 \mathrm{~kg}$

- Nilai Marshall Quotient $=7,2 \mathrm{kN} / \mathrm{mm}$

- Nilai Air Voids $\quad=10,0 \%$

- Nilai film thickness $\quad=5,6 \mathrm{Mm}$

Saran

- Pemanfaatan limbah karet ban luar dapat di uji dengan campuran aspal yang lain seperti, Latasir, ATB, dan lainnya

- Penyusun juga mengharapkan adanya pengembangan lebih lanjut pada penelitian campuran Lataston (HRS-WC) dengan variasi penambahan filler untuk mengisi rongga udara dalam campuran aspal.

- Dalam pencampuran limbah karet, aspal, agregat dan filler harus diperhatikan suhunya karena limbah karet ban luar terbakar pada suhu $\pm 200^{\circ} \mathrm{C}$.

- Kondisi alat harus benar-benar diperhatikan dan factor kalibrasi alat hendaknya diperhatikan juga karena sangat menentukan kesalahan pembacaan data akan mendapatkan hasil yang tidak akurat.

\section{DAFTAR PUSTAKA}

Departemen Pekerjaan Umum. 1999. Pedoman Perencanaan Campuran Beraspal Dengan Pendekatan Mutlak. Jakarta, PT Mediatama Saptakarya (PT Medisa). http://ejournal.umm.ac.id/index.php/jmts/article/view/2037

Direktorat Jendral Bina Marga. 1983. Petunjuk Pelaksanaan Lapis Aspal Beton (Lataston). Jakarta: Departemen Pekerjaan Umum.

Direktorat Jendral Bina Marga. 1996. Pengawasan Mutu \& Pekerjaan (KRMTP). Jakarta: Direktorat Jendral Bina Marga.

Direktorat Jendral Bina Marga, 2007. Uji Laboratorium Bahan Jalan Untuk Campuran Beraspal, Departemen Pekerjaan Umum.

Djarwanto. 1996. Mengenal Beberapa Uji Statistik Dalam Penelitian. Yogyakarta: Penerbitan Liberty.

Pusat Litbang Prasarana Transportasi. 2005. Spesifikasi Umum Bidang Jalan Dan Jembatan. Jakarta: Departemen Pekerjaan Umum.

Sudjana. 1996. Metoda Statistika. Bandung: Penerbitan Tarsito Bandung.

Sukirman, Silvia.1999. Perkerasan Lentur Jalan Raya, penerbit nova,Bandung

Suprapto. 2000. Bahan Dan Struktur Jalan Raya. Jogjakarta: Penerbitan Biro Penerbit.

Wignall, Arthur, dkk. 1999. Proyek Jalan Teori dan Praktek. Terjemahan oleh Aloysius Tjan, Wardo Suwardo. 2003. Jakarta: Erlangga. 